\title{
First overall report of Leptospira infections in wild boars in Poland
}

\author{
Jacek Żmudzki ${ }^{1 *}$, Artur Jabłoński ${ }^{1}$, Agnieszka Nowak' ${ }^{1}$ Sylwia Zębek ${ }^{1}$ Zbigniew Arent ${ }^{3}$, Łukasz Bocian ${ }^{2}$ \\ and Zygmunt Pejsak
}

\begin{abstract}
Background: Recently an increase in the population of wild boars (Sus scrofa) in Europe has been observed. This is important from a zoonotic perspective because it influences directly on the spread of many diseases. For the first time, an extensive survey on the prevalence of Leptospira infections in Polish wild boars was performed. During the hunting season 2012-2014, 3621 blood samples from wild boars were collected. The animals originated from different geographical areas across Poland. Serum samples were tested by a microscopic agglutination test (MAT) for the presence of specific antibodies to the following Leptospira serovars: Icterohaemorrhagiae, Grippotyphosa, Sejroe, Tarassovi, Pomona, Canicola, Bratislava, Autumnalis, Hardjo and Ballum.
\end{abstract}

Results: Antibody titers to all Leptospira serovars except serovar Ballum were found in 377 serum samples (10.4 \%). The highest number of seropositive wild boars was found in the south-eastern part of Poland and in highly urbanized areas such as Silesia and Łódź.

Conclusions: The relatively high prevalence of Leptospira infections in wild boars may constitute a threat to hunters and people having contact with forest lakes or marshlands. The results also indicate that an increasing population of wild boar living close to borders of cities may create additional risk for inhabitants in large urban areas.

Keywords: Leptospirosis, Wild boar, Serology, Prevalence, Zoonosis

\section{Findings}

Leptospirosis is a widely occurring zoonotic disease caused by pathogenic serovars of the genus Leptospira. Wild animals are considered important reservoirs of leptospirosis in humans and livestock. Among the wide range of game species, the wild boar (Sus scrofa) has been identified as an emerging problem in various European countries [1-6]. In the last decade favorable environmental conditions such as mild winters, regular feeding of animals by forest guards, large amounts of natural food available, and changes in agriculture related to intensive cultivation of corn have led to a significant increase in European population of wild boars [7].

Increasing populations of wild boars near suburban areas not only cause a direct threat to inhabitant of highly

\footnotetext{
*Correspondence: jaca@piwet.pulawy.pl

${ }^{1}$ Swine Diseases Department, National Veterinary Research Institute,

Partyzantow 57, 24-100 Pulawy, Poland

Full list of author information is available at the end of the article
}

urbanized regions, [2] but the necessity for population control also constitutes a risk for hunters to become infected by Leptospira sp. [8].

Considering these risks, the aim of this study was to estimate the prevalence of Leptospira infections in the population of wild boars in Poland.

Blood samples $(\mathrm{n}=3621)$ were collected during the hunting seasons 2012-2014 in Poland. The samples originated from 314 counties from all the 16 provinces of Poland (Table 1). The sample size (population proportion) for each province was calculated according to Select Statistical Services program [9].

Samples were collected during evisceration of wild boars shot during legal hunting; authority approval was therefore not required. Blood samples were taken for analysis from the large blood vessels in the neck area. Additionally, peritoneal fluid containing blood was collected. It was subjected to centrifugation at $5000 \mathrm{~g}$ for $20 \mathrm{~min}$ to remove the cellular components of blood, 
Table 1 Geographic distribution and seroprevalence for Leptospira interrogans in 3621 wild boars in 16 Polish provinces between 2012 and 2014

\begin{tabular}{lccc}
\hline Provinces & No of samples & No of seropositive & $\begin{array}{c}\text { \% L. interrogans antibody } \\
\text { positive (95 \% Cl) }\end{array}$ \\
\hline DS & 253 & 16 & $6.3(3.9-10.0)$ \\
KP & 268 & 38 & $14.2(10.5-18.9)$ \\
LU & 372 & 59 & $15.9(12.5-19.9)$ \\
LB & 218 & 23 & $10.6(7.1-15.3)$ \\
LD & 181 & 26 & $14.4(10.0-20.2)$ \\
MP & 187 & 9 & $4.8(2.6-8.9)$ \\
MA & 177 & 17 & $9.6(6.1-14.8)$ \\
OP & 182 & 10 & $5.5(3.0-9.8)$ \\
PK & 251 & 54 & $21.5(16.9-27.0)$ \\
PD & 163 & 19 & $11.7(7.6-17.5)$ \\
PM & 268 & 18 & $6.7(4.3-10.4)$ \\
SL & 187 & 29 & $15.5(11.0-21.4)$ \\
SW & 177 & 9 & $5.1(2.7-9.4)$ \\
WM & 198 & 10 & $5.1(2.8-9.0)$ \\
WP & 242 & 22 & $9.1(6.1-13.4)$ \\
ZP & 297 & 18 & $6.1(3.9-9.4)$ \\
Total & 3621 & 377 & $10.4(9.5-11.4)$ \\
\hline DSL & & 9
\end{tabular}

DS Lower Silesia, KP Kuyavian-Pomerania, LB Lubuskie, LD Łódzkie, LU Lubelskie, MA Masovia, MP Leser Poland, OP Opolskie, PD Podlaskie, PK Subcarpathia, PM Pomerania, SL Silesia, SW Świętokrzyskie, WM Warmia-Masuria, WP Greater Poland, ZP West Pomerania

tissue debris and bacterial contamination. The obtained supernatant was used for serological testing. Animals, which had been shot in the abdomen, were not included in the study. All samples were stored at $-18{ }^{\circ} \mathrm{C}$ until analysis.

Serum samples were tested by microscopic agglutination test (MAT) using a range of ten Leptospira serovars representative of nine serogroups found in Europe: Icterohaemorrhagiae (strain RGA, representing serogroup Icterohaemorrhagiae), Grippotyphosa (strain Moskva V, serogroup Grippotyphosa), Sejroe (strain M84, serogroup Sejroe), Tarassovi (strain Perepelicyn, serogroup Tarassovi), Pomona (strain Pomona serogroup Pomona), Canicola (strain Hond Utrecht IV, serogroup Canicola), Bratislava (strain S/820834, serogroup Australis), Autumnalis (strain Akiyami, serogroup Autumnalis), Hardjo (strain Hardjoprajitno, serogroup Sejroe) and Ballum (strain MUS127, serogroup Ballum) [10, 11]. The reference strains were provided by the Veterinary Sciences Division, AFBI, OIE Leptospira Reference Laboratory, Belfast.

Each serovar was grown in $10 \mathrm{ml}$ volumes of Ellinghausen-McCullough-Johnson-Harris (EMJH) medium, incubated at $28{ }^{\circ} \mathrm{C}$ for $6-10$ days depending on the serovar. The concentration of bacteria was adjusted to $1-2 \times 10^{8}$ cells $/ \mathrm{ml}$ by cell count using a Helber counting chamber. The sera were initially screened for antibodies to the ten serovars at a final dilution of 1:100. When agglutination occurred, the relevant sera were end-point tested using doubling dilutions ranging from 1:100 to 1:25,600. The titre was defined as the highest dilution where $\geq 50 \%$ of the antigen was agglutinated.

Calculation of Pearson's and Spearman's correlations and spatial analysis, STATISTICA (data analysis software system), version 10 (StatSoft, Inc.) and ArcGIS 10.1 SP1 for Desktop Standard (ESRI, Inc.) were used for data analyses. Wild boar demographics was derived from the Polish Hunting Association-PZL [12] and data were converted from province to county level.

Antibodies against Leptospira serovars were found in 377 samples $(10.4 \%)$. The highest prevalence was found in the province Subcarpathia (21.5\%), but other provinces also had wild boar populations with a high prevalence of Leptospira antibodies (Table 1; Fig. 1). Statistical analysis showed a statistically significant correlation between the seroprevalence and the density of wild boars (significance level alpha $=0.05$ ) but the correlation was weak: Pearson's correlation coefficient was equal to $-0.20(\mathrm{P}=0.010)$ and Spearman's rank correlation coefficient confirmed the result of Pearson's correlation and amounted to $-0.20(\mathrm{P}=0.013)$. The most common serovars were Hardjo, Pomona, Grippotyphosa and Bratislava (Table 2). Of the 377 Leptospira positive samples, $81 \%$ had titers against one serovar, while $19 \%$ had positive titers against two or more $(\leq 7)$ serovars. These findings may be due to infections by more serovars or may reflect 


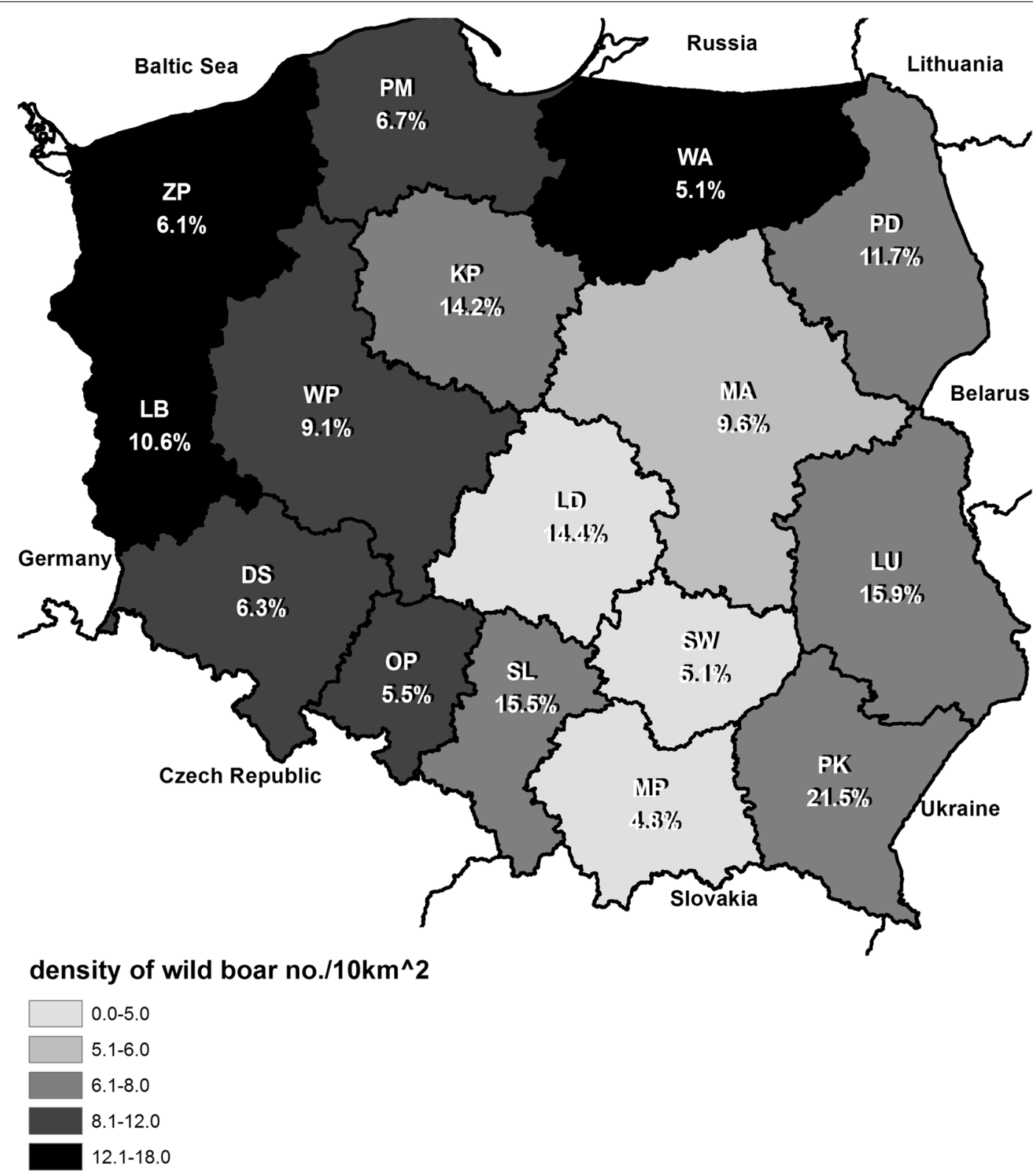

Fig. 1 Geographic distribution of wild boars being seropositive for Leptospira interrogans in Poland. DS Lower Silesia, KP Kuyavian-Pomerania, LB Lubuskie, LD Łódzkie, LU Lubelskie, MA Masovia, MP Leser Poland, OP Opolskie, PD Podlaskie, PK Subcarpathia, PM Pomerania, SL Silesia, SW Świętokrzyskie, WM Warmia-Masuria, WP Greater Poland, ZP West Pomerania

cross-reactions between strains of different serogroups [13]. The observed seroprevalence is at the same level as found in other European countries, especially Spain (12\%) [14] and Germany (18 \%) [2]. In Germany, a high seroprevalence was found near the city of Berlin having a population of 3.5 million people [15]. Similarly, we found a high percentage of positive samples $(15.5 \%)$ in the Upper Silesian metropolitan area (population 2.7 million people) (Fig. 1) [15]. Data from Germany and Poland indicate that wild boars living close to city boarders with high human population density may be a threat to the inhabitants [2].

The seroprevalence of Leptospira in wild boars varies considerable across Europe from 65.4, 45.8 and $31.9 \%$ in Portugal, [5], Slovenia [6] and Croatia [3], respectively to $2.6 \%$ in Italy [16] and $3.1 \%$ in Sweden [17]. The variation in seroprevalence across regions may be related to difference in populations of wild small mammals, which 
Table 2 Distribution of Leptospira interrogans antibody titers for 377 positive wild boars hunted during season 20122014 in Poland

\begin{tabular}{|c|c|c|c|c|c|c|c|}
\hline \multirow[b]{2}{*}{ Serovar } & \multicolumn{7}{|c|}{ No of antibody-positive samples (\%) } \\
\hline & $1: 100$ & 1:200 & $1: 400$ & $1: 800$ & 1:1600 & $1: 3200$ & Total \\
\hline Icterohaemorhagiae & $8(0.2)$ & $3(0.1)$ & $6(0.2)$ & 0 & 0 & 0 & $17(0.5)$ \\
\hline Grippotyphosa & $26(0.7)$ & $34(0.9)$ & $20(0.6)$ & $1(0.03)$ & $1(0.03)$ & 0 & $82(2.3)$ \\
\hline Sejroe & $3(0.1)$ & $3(0.1)$ & $1(0.03)$ & 0 & 0 & 0 & $7(0.2)$ \\
\hline Tarassovi & $32(0.9)$ & $9(0.2)$ & $2(0.1)$ & $2(0.1)$ & 0 & 0 & $45(1.2)$ \\
\hline Pomona & $50(1.4)$ & $29(0.8)$ & $25(0.7)$ & $5(0.1)$ & $2(0.1)$ & $1(0.03)$ & $112(3.1)$ \\
\hline Canicola & $14(0.4)$ & $1(0.03)$ & 0 & 0 & 0 & 0 & $15(0.4)$ \\
\hline Bratislava & $29(0.8)$ & $20(0.6)$ & $9(0,2)$ & $5(0.1)$ & $1(0.03)$ & 0 & $64(1.8)$ \\
\hline Autumnalis & $9(0.2)$ & $7(0.2)$ & $5(0.1)$ & $2(0.1)$ & $1(0.03)$ & 0 & $24(0.7)$ \\
\hline Hardjo & $54(1.5)$ & $42(1.2)$ & $25(0.7)$ & $3(0.1)$ & $1(0.03)$ & 0 & $125(3.5)$ \\
\hline
\end{tabular}

act as maintenance hosts for the various Leptospira serovars [18], although differences in study design and methods may also account for some of the differences. For example, recent studies carried out in northern Portugal demonstrated a high rate of titers against the new serovar Altodouro, which was isolated from Mus musculus in the region [19].

The seroprevalence of Leptospira infection in wild boars in Poland has been studied previously but that study was limited to the northern part of the country [20]. Unexpectedly, the results of our study indicated that the number of positive animals detected in this region was comparable to the findings of the previous study with an overall prevalence of infection in animals estimated at $25 \%$.

The population density of wild boars in many European countries including Poland has been continuously increasing for many years. During the last 30 years, this has resulted in a more than five-fold increase in the Polish wild boar population, initially reaching 46,000 animals in 1985 to more than 282,000 wild boars in 2015 [12]. An increasing population of wild boar results in more frequent contact between animals, which may lead to an increase in the spread of many infections.

Leptospirosis may be transmitted from wild boars to domestic pigs, although depending on pig production facilities. The serovars Pomona and Sejroe have been reported as the most common in domestic pigs in Poland $[21,22]$, but antibodies to these serovars were infrequent in our study (3.1 and $0.2 \%$, respectively) (Table 2 ). The study shows that wild boars in Poland are exposed to Leptospira sp., but that the seroprevalence varies across provinces. The serovars Hardjo and Pomona are the most common. The seroprevalence for Leptospira is particular high in the province of Subcarpathia. However, the epidemiology of leptospirosis in wild boars in Poland requires further studies, which should include isolation and typing of Leptospira strains.

\section{Authors' contributions}

JZ designed and coordinated the study. SZ and AN were responsible for data analysis. LB performed the statistical analysis. JZ, ZA, AJ and ZP collectively participated in authoring the manuscript. All authors read and approved the final manuscript.

\section{Author details}

${ }^{1}$ Swine Diseases Department, National Veterinary Research Institute, Partyzantow 57, 24-100 Pulawy, Poland. ${ }^{2}$ Epidemiology and Risk Assessment Department, National Veterinary Research Institute, Partyzantow 57, 24-100 Pulawy, Poland. ${ }^{3}$ OIE Leptospira Reference Laboratory, Veterinary Sciences Division, AFBI, Stoney Road, Stormont, Belfast, Northern Ireland BT43SD, UK.

\section{Acknowledgements}

We are grateful to the hunters of all 16 provinces; without their help this investigation would not have been possible. The authors would like to warmly thank Colm Gilmore and Krzysztof Śmietanka for useful comments and editing of the manuscript. Many thanks to Agnieszka Stolarek for creating the map and tables. This study was supported by the Polish National Science Centre (Grant number 2013/09/B/NZ7/02563).

\section{Competing interests}

The authors declare that they have no competing interests.

Received: 7 August 2015 Accepted: 5 January 2016

Published online: 12 January 2016

\section{References}

1. Cano-Manuel FJ, López-Olvera J, Fandos P, Soriguer RC, Pérez JM, Granados JE. Long-term monitoring of 10 selected pathogens in wild boar (Sus scrofa) in Sierra Nevada national park, southern Spain. Vet Microbiol. 2014;174:148-54.

2. Jansen A, Luge E, Guerra B, Wittschen P, Gruber AD, Loddenkemper C, et al. Leptospirosis in urban wild boars, Berlin. Germany. Emerg Infect Dis. 2007;13:739-42

3. Slavica A, Cvetnić Ž, Konjević D, Janicki Z, Severin K, Dežđek D, et al. Detection of Leptospira spp. serovars in wild boars (Sus scrofa) from continental Croatia. Veterinarski Arhiv. 2010;80:247-57.

4. Treml F, Pikula J, Holesovska Z. Prevalence of antibodies against leptospires in the wild boar (Sus Scrofa L., 1758). Vet Med. 2003;48:66-70.

5. Vale-Gonçalves HM, Cabral JA, Faria MC, Nunes-Pereira M, Faria AS, Veloso O, et al. Prevalence of Leptospira antibodies in wild boars (Sus 
scrofa) from northern Portugal: risk factor analysis. Epidemiol Infect. 2015;143:2126-30.

6. Vengust $\mathrm{G}$, Lindtner-Knific R, Zele D, Bidovec A. Leptospira antibodies in wild boars (Sus scrofa) in Slovenia. Eur J Wildl Res. 2008:54:749-52.

7. Acevedo P, Vicente J, Höfle U, Cassinello J, Ruiz-Fons F, Gortazar C. Estimation of European wild boar relative abundance and aggregation: a novel method in epidemiological risk assessment. Epidemiol Infect. 2007;135:519-27.

8. Richard S, Oppliger A. Zoonotic occupational diseases in forestry workers-Lyme borreliosis, tularemia and leptospirosis in Europe. Ann Agric Environ Med. 2015;22:43-50

9. Select Statistical Services Limited. Registered in England and Wales No. 07554240. http://www.select-statistics.co.uk/ sample-size-calculator-proportion.

10. OIE (Office International des Epizooties), 2014. Leptospirosis. www.oie.int/ fileadmin/Home/eng/Health_standards/tahm/2.01.09_LEPTO.pdf.

11. Wolff JW. The laboratory diagnosis of leptospirosis. Illinois: Charles $C$. Thomas Publishers; 1954. p. 31-51.

12. Polish Hunting Association-PZL. Warsaw. 2015. http://www.zopzl-opole. $\mathrm{pl} /$ ?wpfb_dl=397.

13. Levett PN. Leptospirosis. Clin Microbiol Rev. 2001;14:296-326.

14. Vicente J, León-Vizcaíno L, Gortázar C, Cubero MJ, González M, MartínAtance P. Antibodies to selected viral and bacterial pathogens in European wild boars from southcentral Spain. JWildl Dis. 2002;38:649-52.
15. Eurostat. http://ec.europa.eu/eurostat/web/

population-demography-migration-projections/population-data.

16. Montagnaro S, Sasso S, De Martino L, Longo M, lovane V, Ghiurmino G, et al. Prevalence of antibodies to selected viral and bacterial pathogens in wild boar (Sus scrofa) in Campania region Italy. J Wild Dis. 2010;46:316-9.

17. Boqvist S, Bergström K, Magnusson U. Prevalence of antibody to six Leptospira servovars in Swedish wild boars. J Wildl Dis. 2012;48:492-6.

18. Ellis WA. Control of canine leptospirosis in Europe: time for change? Vet Rec. 2010;167:602-5.

19. Paiva-Cardoso Md, Arent Z, Gilmore C, Hartskeerl R, Ellis WA. Altodouro, a new Leptospira serovar of the Pomona serogroup isolated from rodents in northern Portugal. Infect Genet Evol. 2013;13:211-7.

20. Krawczyk M. Serological evidence of leptospirosis in animals in northern Poland. Vet Rec. 2005;156:88-9.

21. Wasiński B, Pejsak Z. Occurrence of leptospiral infections in swine population in Poland evaluated by ELISA and microscopic agglutination test. Pol J Vet Sci. 2010;13:695-9.

22. Wasiński B. Infections of swine caused by Leptospira serovars of serogroup Sejroe - possibilities of recognition with the use of PCR. Bull Vet Inst Pulawy. 2014;58:521-6.

\section{Submit your next manuscript to BioMed Central and we will help you at every step:}

- We accept pre-submission inquiries

- Our selector tool helps you to find the most relevant journal

- We provide round the clock customer support

- Convenient online submission

- Thorough peer review

- Inclusion in PubMed and all major indexing services

- Maximum visibility for your research

Submit your manuscript at www.biomedcentral.com/submit
() Biomed Central 